\title{
集光式太陽光発電システムの動向
}

\author{
北村章夫*
}

\section{Progress of Solar Concentrated Electric Power Generation}

\author{
Akio Kitamura
}

\section{Synopsis}

The concentrated Photovoltaic power generating system (PV system) is now thought to be a more advanced system than the solar thermal generating system. The PV system was popularized overseas in the 1980's because the solar thermal generating system was very expensive.

Japan once partook in developing the PV system; this included installation and operation tests. This article will present arguments for the re-development and expansion of the PV system.

An examination of previous attempts to develop the PV system, and what kind of progress they followed, will be useful for further development.

\section{1 . 集光式太陽光発電システムとは}

集光式太陽光発電システムとは文字通り地表では希薄 な太陽エネルギーをレンズや反射鏡で集めて高エネル ギー密度化し, 弚の高密度エネルギーを発電に利用しよう とするものである .また , 化石燃料枯渴の危惧や，地球環 境問題などの解決策の一環として，自然エネルギー有効活 用が促されている.集光式太陽光発電システムも自然エネ ルギーである太陽エネルギーを利用した発電システムで あることは言うまでも無い.この発電システムは既に光の 頂点を極め, 弚の後, 盛衰を繰り返し, 今なお撤退と復活 を続けている新発電システムである.弚れゆえ，数ある新 発電システムの中でも極めて珍しい動きをしているとい うことができる.しかしながら，なぜ光のような動きをし てきたかについてはほとんど調査・分析されず，したがっ て周知もされていない.この集光式太陽光発電システムが 「なせ撤退と復活をつづけている」のか，あるいは「現状 がどうなっている」のかを知るためにも，さらには「将来 を予測する」上でも，これまでの経緯をたどらなければな らない.
この集光式発電システムの開発に際し,「どのような事 態がおきたのか，光れらが，どのような結果となったか」 の顛末について, 従来型発電システム (電気事業者が言う ところの発電・送配電) の観点から振り返ってみると, 良 く理解できる．まず，「集光式太陽光発電システム」を語 る上で無視できないのが，「太陽熱発電システム」である． なぜなら「集光式太陽光発電システム」は高価な太陽電池 の使用量を減少させることによる経済性を追及した発電 システムとして, 開発されはじめたが, 弚れとは別に「太 陽熱発電システム」にとって致命的な欠点を修正・改良し たところの後継システムとして登場した一面もあるから である、「太陽熱発電システム」は太陽エネルギーを集め る装置として主に反射鏡を使って集熱している.したがっ て太陽熱発電システムは「集熱式太陽エネルギー発電シス テム」と呼んだほうが今となっては適切かもしれない．

\section{2 . 集光，集熱は古くから親しま れている技術}

集光式太陽光発電システムとはいうまでも無く地表で は希薄な太陽エネルギーをレンズや反射鏡で集めて高密 
度化し，乥こに太陽電池を置き，発電するものである.太 陽エネルギー利用の集光集熱システムは決して新しいも のでも，特別なものではない . ギリシャの古い話の中に， 手鏡を持った多数の女性が海岸に集まり，いっせいに光を 海に向け反射させ,敵の艦船を炎上させた話があり，日本 でも金属溶解のための太陽炉などは百年以上前から導入 されていた .今でも，あちこちで，太陽熱エネルギーに親 しむイベントとして小さな反射板やアルミ箔を使って，野 外クッキングなどを楽しむ催し物が開かれることがある． これもずいぶ沉古くから行われているが，天候の悪い日に あたると光れはもう大変みじめなことになる

\section{3 . 太陽熱発電システム固有の問題点}

1970 年から 1980 年代にかけて 米国では数十 MW 級の 太陽エネルギー発電システムいわゆる太陽熱発電所がさ かんに研究開発され建設され，実用化された (Fig.1 およ びFig.2) .

反射鏡やレンズにより太陽エネルギーを集め，光の熱で

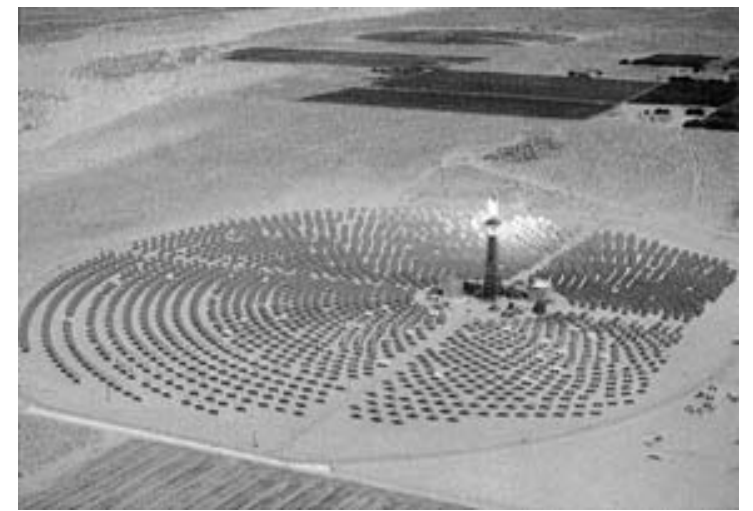

Fig.1. Tower type concentration solar thermal power generation plant (10MW Solar - One USA).

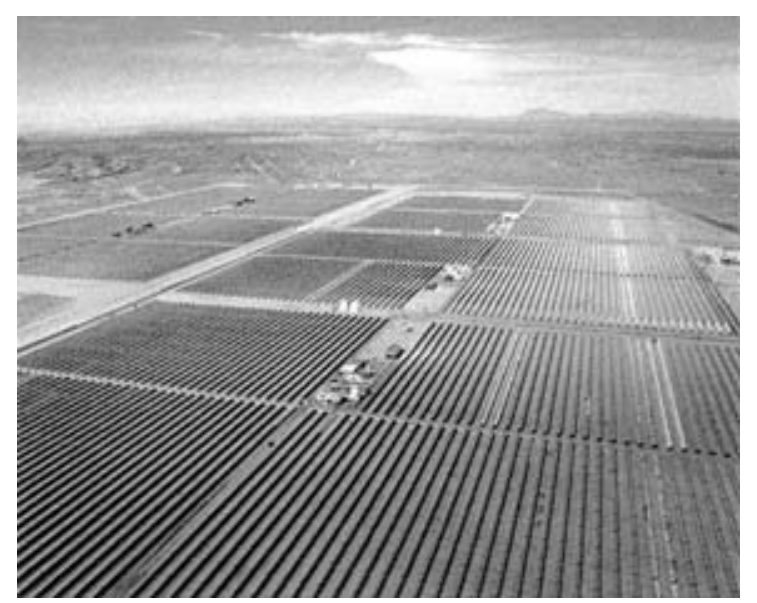

Fig.2. Trough concentration type solar thermal power generation plant (350MW LUZ's - California USA).
水を沸騰させ蒸気を作り，乥の蒸気でタービンを回し発電 機を駆動するという,いわゆる集熱式太陽エネルギー発電 システムである (Fig.3および Fig.4) .

当時 ,ロスアンゼルスやラスベガス発のグランドキャニ オン観光ツアーに向かう飛行機が,アリゾナ砂漠の円形農 場とともに巨大な太陽熱発電所の上空を飛行することが 話題となった . 日本でも 1000 キロワットクラスの集光式 太陽熱発電所が開発された.香川県の仁尾町に設置された 旧サンシャイン計画におけるタワー集光 (熱) 型太陽熱発 電システムとトラフ型集光 (集熱) 太陽熱発電システムで ある.米国の太陽熱発電システムはかなり長期間, 運転さ れており，いまなお，改良開発が続けられているといわれ ている.中東のイスラエルなどでも,盛んに建設と研究開 発か続けられているといわれている、一方,日本では、「太 陽熱発電システム」はこの発電システムに固有の技術的問

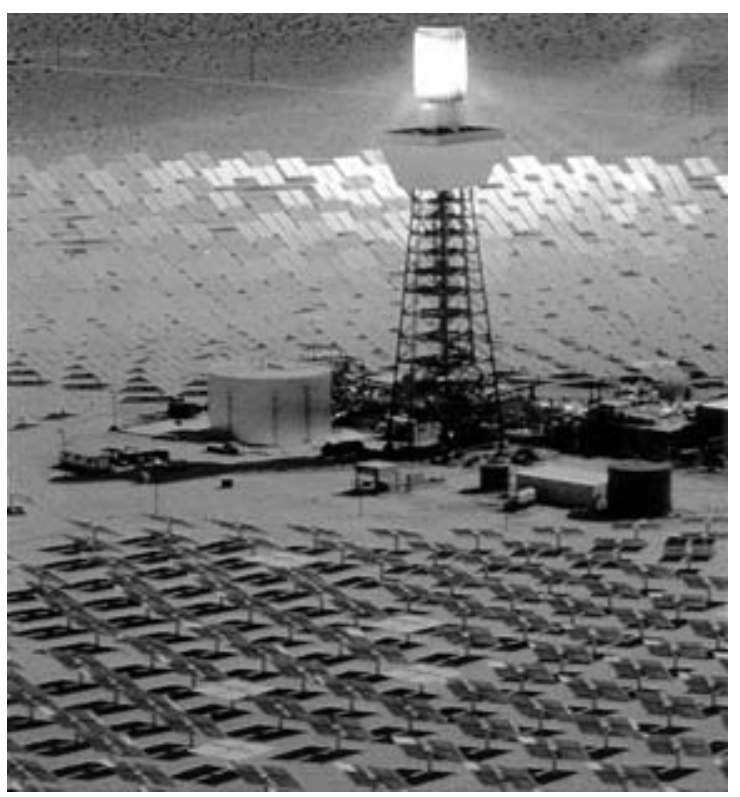

Fig.3. Tower mounted thermal receiver (10MW Solar - One USA).

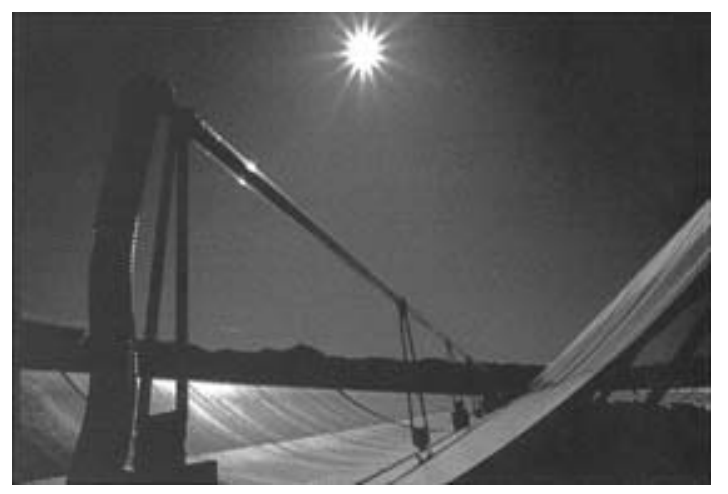

Fig.4. Line-focusing parabolic trough concentrator and thermal receiver (350MW LUZ's - California USA). 
題のみならず，日本固有の気候的・地理的問題にも直撃さ れた .弚の問題を許容できるシステムの改良は,かなりの 試行錯誤を必要としており，光の実現があまりにも厳し く，高コストであったことから，開発は終止された .

\section{4 . 太陽熱発電システムの難しさ}

太陽熱発電所システムの集熱部は蒸気タービンを駆動 するために,前もって定められた高い蒸気温度と高い蒸気 圧を発生させなければならない .さらに关のような高温・ 高圧蒸気を，ある程度の運転時間を継続させるために，必 要量を冷やさずに蓄積しなければならない .この高温高圧 蒸気を作り出すための日射強度設定が極めて難しい命題 となる.低い日射強度でも十分に駆動するように設計され たシステムは集光倍率を高くしなければならない .乥の結 果, 設置面積も広大になり規模も大きくなる.しかしなが ら，低日射用に作られたシステムは，強い日射のときには 予定以上に高温となることから過熱防止対策などが必須 となる.これは極めて不経済なシステムとなる.他方，高 い日射強度て駆動するように設計されたシステムは集光 倍率を低くできる．したがって，規模は小さくすることが できるが, 発電目的を達する日射強度の出現率が低くな り,結果として期間発生電力量の不足を引き起こすことに なる.こちらも不経済なシステムとなる.特に日本は，雲 ひとつ無い快晴日が年間に数えるほどしかなく，まさに雲 だらけの，しかも弚の雲が高速で移動する季節風地帯に位 置する.このことは太陽熱発電システムにとって, 安定し た蒸気発生量を得ることか難しいだけでなく,高速で変動 する熱ストレスも加わることになり，悩ましいことにな る.弚の結果, 米国や中東, 北アフリカなどの砂漠地帯で は,十分に性能や経済性を発揮した発電システムであった が,「日本では無理」との結論が生まれてきた . このとき 生まれた「日本では適切ではない」との概念が，後の集光 式太陽光発電システムにも根強く影響を与え，さらに誤解 も生まれることになる .) 太陽熱発電システムの最適化構 成は「作って運転してみなければわからない」事が多い． したがって，かなりのカットアンドトライが必要となる が, システムを作り替えることは負担が大きい .このよう な場合，いわゆるシミュレーション，机上検討を十分にや ればよいとの意見が出てくるが，なにしろ，「実証試験・ 実測をもとにした豊富て確実な基礎データ」が全く無い か，あっても不十分であれば, 弚れはより難しいことにな る.さらに太陽熱発電システムには，気候的な条件だけで はなく, システム構造にも問題は多い, 大幅でかつ, 高速 で変動する入射エネルギーに対応する蒸気発生システム
には,かなりの熱ストレスが加わることになるため，光の 対応は大変である.また比較的問題が無いと思われる反射 鏡にしても，実際には日射・大気・風雨に暴露されること による腐食や酸化，さらには反射鏡の表面に付着する塵埃 などにより大幅な反射率低下を招く．長期間，良好な反射 率を維持する鏡面は材料の面からも構造の面からも，意外 と難しいものである (Fig.3 および Fig.4) . その難問を解 決する対策として保護膜を採用すると, 今度は保護膜固有 の難問題がでてくることになる .

\section{5 . 太陽電池を使った発電システム への期待}

入射エネルギーの変動に対する蒸気発生システムを構 成することの難しさや，装置間マッチング，さらには，太 陽エネルギーの入り口であり比較的簡単と見られていた 反射鏡システムすら，(これにはさらに厄介な太陽追尾シ ステムが付随する) 開発の難しさか随所に見え始め, これ を一挙に解決するための方策が切実に求められるように なった，弚のころ, 高性能なシリコン結晶半導体素子が整 流器, 光電素子から光電池, さらには太陽電池と呼び名を 変えて登場してきた . 太陽電池は太陽熱発電システムが 持っている固有の重い課題を完全に雨散霧消させること ができるものとして ,まさに救世主のように思われたのは 無理も無いことであった.弚の結果，光れまで開発を進め てきた集熱・発電関係者のみならず, 発電とは無関係で あった半導体や太陽電池などのエレクトロニクス関係者, あるいは自動制御関係者,太陽エネルギーに造詣の深い光 学研究者などがこの発電システムに何らかの形で参加す ることになる.発電についての経験も知識も持ち合わせて いないとしか思えない新発電プロジェクトや光起電効果 領域内に留まる中途半端なプロジェクトが登場し始めた のもこのころである.集光式太陽光発電システムが盛衰を 繰り返すことになる素地もこの頃に出来たと思われる．

\section{6 . 集光式太陽光発電システムの 優位性・合理性}

集光式太陽光発電システムの発電部分は太陽電池であ る.太陽電池は太陽光エネルギーを直接，電気に変換す る.太陽電池ならば，「太陽熱発電」の場合に取り扱いに 難しさを伴い, 厄介ものであった蒸気発生装置も蒸気ター ビンも回転式電磁発電機も一気に飛び越え, (発生する電 気は直流であるにしても，) 直接電気を発生させることが できるのである .

太陽電池は地表に発生するの日射の強弱程度はおろか， 


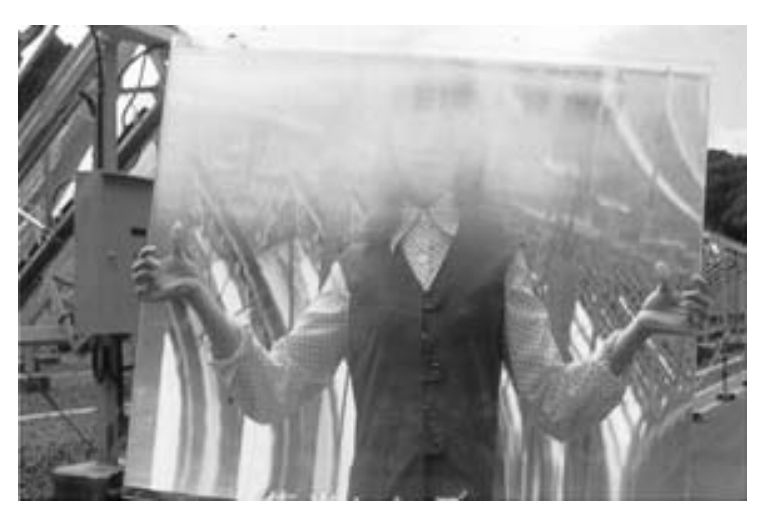

Fig.5. Liner focus Fresnel lens for 1 axis tracker (NEC Corporation).

光の何十倍もの入射エネルギーの強弱にも高速で反応し， しかもこの間,变換効率は,ほとんと変わらないという優れ た性質も持っている．このような太陽電池の起電特性は， 太陽熱発電システムでの「日射強度の設定」という難題を 解消する.しかも，太陽電池は高価であったにしても，集 光倍率分だけ低下させることが出来ることや, 集光装置や 追尾装置などの開発は太陽熱発電で十分経験済みである ことからコスト競争力も十分にあると評価され，開発に拍 車がかった，集光集熱システムとしてはいろいろ問題の 多い反射鏡についても，弚れに代わるものとして，大型プ ラスチック・フレネルレンズが開発されており，これも欠 点の大部分を克服することができるとして，さらに光の全 体評価を補強することになった (Fig.5) .

\section{7 . 集光式太陽光発電システムの 全盛期}

太陽熱発電システムがかかえる主要な問題から解き放 なたれた集光式太陽光発電システムは，弚のうえ日射変動 の重荷からも開放され，全盛期を迎えることになる.1970 年代後半から 1980 年代前半にかけて，たくさんの集光式 発電システムが米国を始め,サウジアラビアなど中東産油 国でも，導入され，運用された .このころ作られた集光式 発電システムは光のほとんどが集光器にプラスチックフ レネルレンズを採用していた、反射鏡を採用したものはほ とんど姿を消した .この集光器を駆動するシステムとし て，赤道儀方式（主駆動軸を地球の自転軸に合わせる， Fig.6 およびFig.7) とターンテーブル方式 (駆動軸を地球 の重心に合わせる ,Fig.8 およびFig.9)の 2 方式が大勢を 占めた .日本でも, 若干遅れてはいたが, 集光式太陽光発 電の研究開発が進められており，兴のうちの数システム が, 害際に建設され運転された (Fig.6〜 Fig.9) .この中 には集光式発電に加えて,高温に晒される太陽電池の冷却 熱も合わせて利用する熱・電気ハイブリッド方式 (Fig.9)

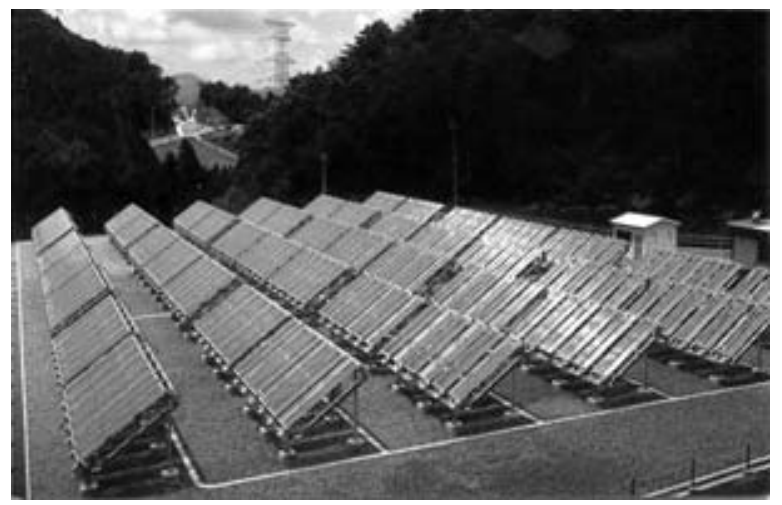

Fig.6. Equatorial scope type, 1 axis tracking PV generation with linear-focus Fresnel lens (50kW : NEC Corporation, Nissin Electric Co., Ltd., Kansai Electric Power Co., Inc.).

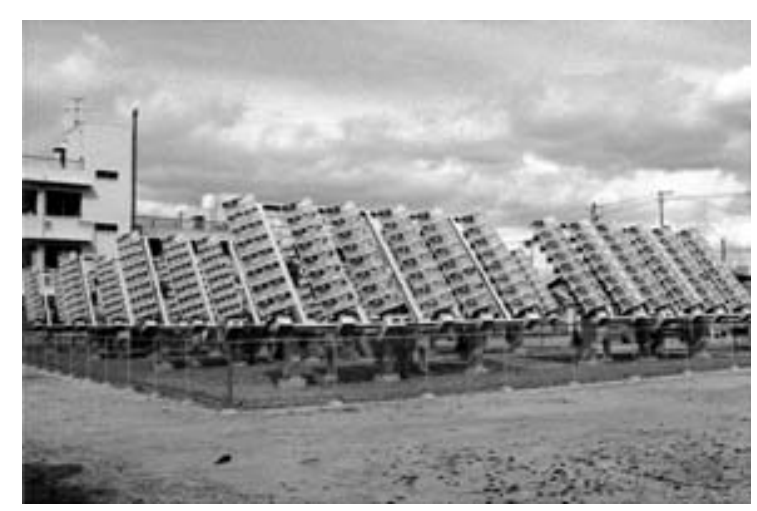

Fig.7. Equatorial scope type, 2 axis tracking PV generation with point-focus lens (10kW : Sumitomo Electric Industries, Ltd., NEC Corporation, Nissin Electric Co., Ltd., Kansai Electric Power Co., Inc.).

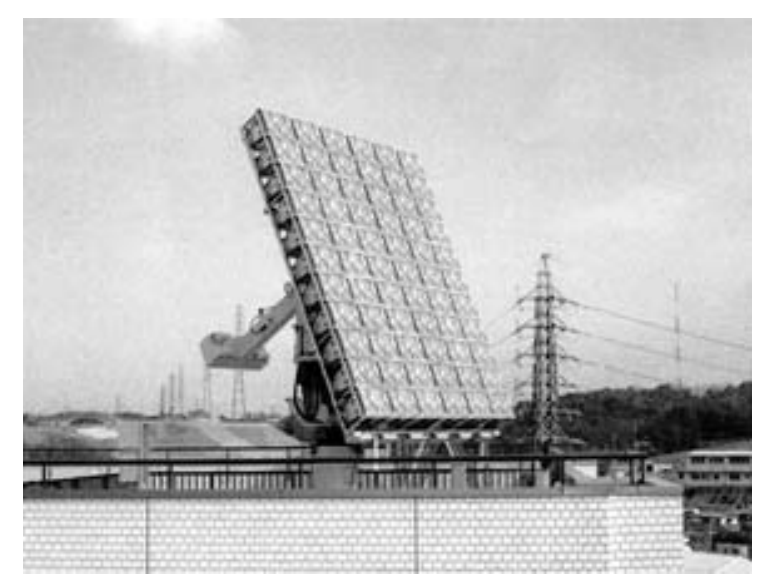

Fig.8. Turntable type 2-axis-tracking concentration power generation system with GaAs solar cells (Mitsubishi Electric Corporation, Cyubu Electric Power Co., Inc.).

やリニアフレネルレンズの特性を生かし,追尾機構を仰角 固定，時角追尾のみにした一軸追尾システム (Fig.6) やガ リウム砒素系の高变換効率半導体太陽電池を採用した画 期的なシステム (Fig.7 および Fig.8) が含まれていた . 


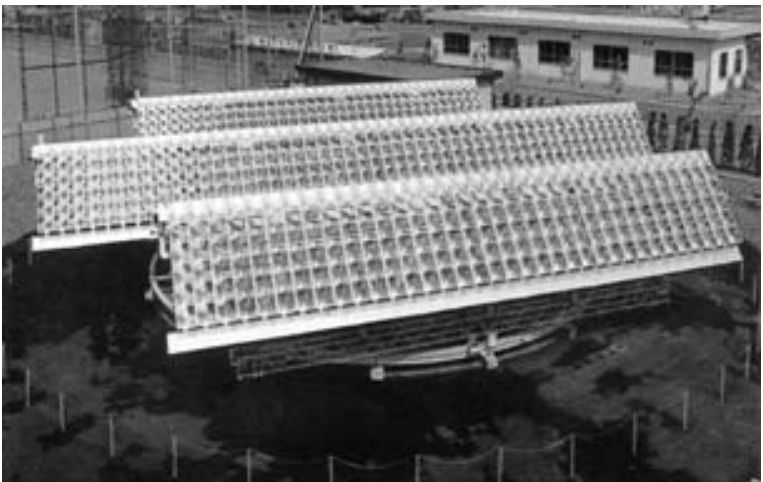

Fig.9. Turntable type, 2-axis-tracking PV generator and thermal collector hybrid system(NEDO, Sharp Corporation).

\section{8. 集光式発電システムの構成}

集光式太陽光発電システムの主要構成要素は集光型太 陽電池, 集光装置, 追尾装置, 直流交流電力変換装置, 電 力分電盤であり,近年は電力分電装置に代えて系統連系装 置が付く.

(1) 集光型太陽電池

集光型太陽電池は特別なものではなく，集光による高密 度入射エネルギーに耐える太陽電池であれば良い.高密度 入射エネルギーは出力電流密度の増大と太陽電池表面の 高温化をもたらす.弚のため表面電極パターンが平板式の それとは異なることになり,裏面には簡単な自然空冷タイ プの冷却部品がつく (Fig.10) . 高温部の冷却に流体を用 いて,電気のみならず熱をも手に入れようとする発想もあ るが,集熱システムが新たに加わることによる機構の複雑 化と光れに伴う信頼度低下によりほとんど成功していな い.

\section{(2) 集光装置}

集光装置の主体をなすものは集光レンズである.集光レ

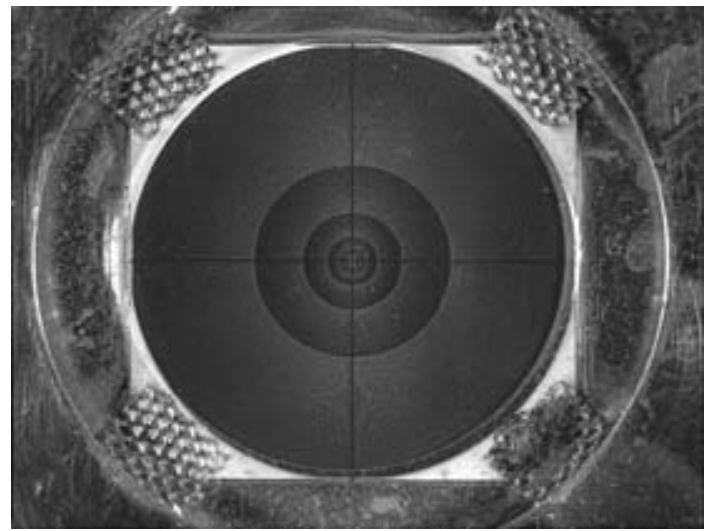

Fig.10. GaAs concentration solar cell (concentration ratio 200, point focus type) (Sumitomo Electric Industries, Ltd.).
ンズとしてはプラスチック・フレネルが圧倒的に多く採用 される.プラスチックフレネルレンズは自由度が大きいた め,さまざまなアイデアを取り入れながら発展した (Fig.5) . 太陽光発電に使用される集光レンズは太陽電池の 性能を適切に引き出すように作られなければならないが， 弚れだけではなく，追尾駆動装置にもできるだけ負担をか けないよう配慮しなければならない.集光レンズをふくし 集光装置については, やがて, 独自の評価基準と価值観 (たとえば,太陽電池を評価する測光条件とは異なるもの) をもって，乥れだけを専門とする研究開発分野が生まれる までになった．この分野の研究開発は独自の進展を遂げ， やがては, 新規集光装置が提案され, 弚の実用化を促すた めに,新たな集光式太陽光発電システムの開発を求めると いう事態すら発生するようになった. 集光フレネルレンズ 単体でも，集光型太陽電池ごとに特化したものであったは ずが,やがて独自に進歩を遂げ，太陽電池よりはるかに開 発が進み, やがて, 対応可能な太陽電池の登場を待つか, あるいは登場を促すかと言われるまでに至った . さらに は,太陽電池では実現不可能な領域にまで達するレンズも 出てきた . まさに,「太陽電池主導から，フレネルレンズ 主導へと本末転倒状態が起きた」といえる．

(3) 太陽追尾駆動装置

太陽電池と集光レンズを組み合わせたパネルを正確に 太陽に正対させる装置が太陽追尾駆動装置である.太陽は 地表から見れば毎日, 東から上り西へ沈み,地平線から上 り頭上高く達したあと再び地平線下に沈むと言う，いわゆ る時角と仰角の 2 軸の動きをする.したがって太陽追尾駆 動装置は基本的に 2 軸追尾機能でなければならない (Fig.11).

基本軸に地球の自転軸を採用するか，重心軸を採用する かで, 大きく追尾駆動装置は変化する.地球の自転軸を基

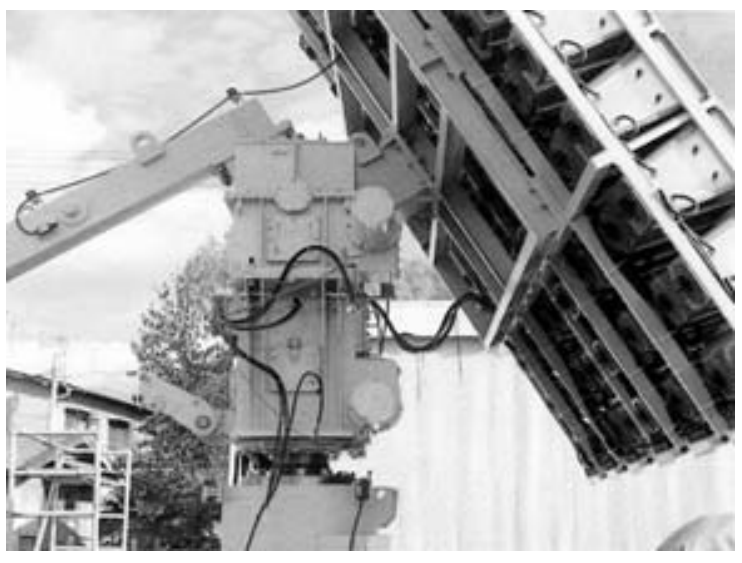

Fig.11. Turntable type 2-axis-tracking system (Mitsubishi Electric Corporation, Cyubu Electric Power Co., Inc.). 
本軸として作られたものが赤道儀タイプであり (Fig.12)， 地球の重心を基本に作られたものがターンテーブルタイ プである.開発初期段階では赤道儀式の簡素なシステムに 対し (Fig.13) ，ターンテーブルタイプでは駆動電力の大 きさや躍動ソフトウエアの難しさが目立ったが , 現在で は，改良され両者の相違点は目立たなくなっている.簡潔 化された太陽追尾駆動装置は, 米国や欧州では, 発生電力 量増収を目的に, 平板式 (無集光) 太陽光発電システムに も，積極的に採用されている (Fig.14 およびFig.15)．集 光式太陽光発電用に開発スタートした太陽追尾駆動装置 は,いまや，集光式を越えた領域に進出している(Fig.16)． (4) 直流交流電力変換装置

太陽光発電装置の出力を利用するには直流交流变換を 行うことになる.これを行うものが直流交流電力変換装置 (インバータ) である .太陽電池 , レンズ, 追尾駆動装置 のユニットが作り出す電気は,極めて激しく変動する直流 電気である.変動速度や変動幅は「平板式太陽光発電シス テム」とは比べようがないほど，まさに集光倍率で増幅し

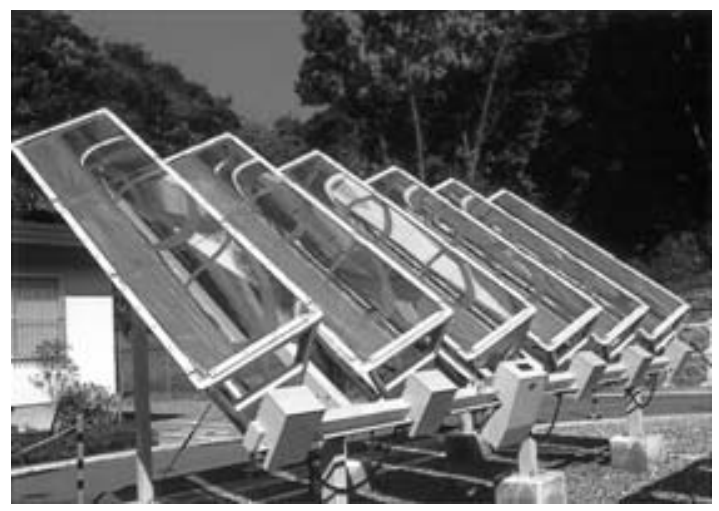

Fig.12. Equatorial scope type, 1 axis tracking PV generation unit with linear-focus Fresnel lens(NEC Corporation, Kansai Electric Power Co., Inc.).

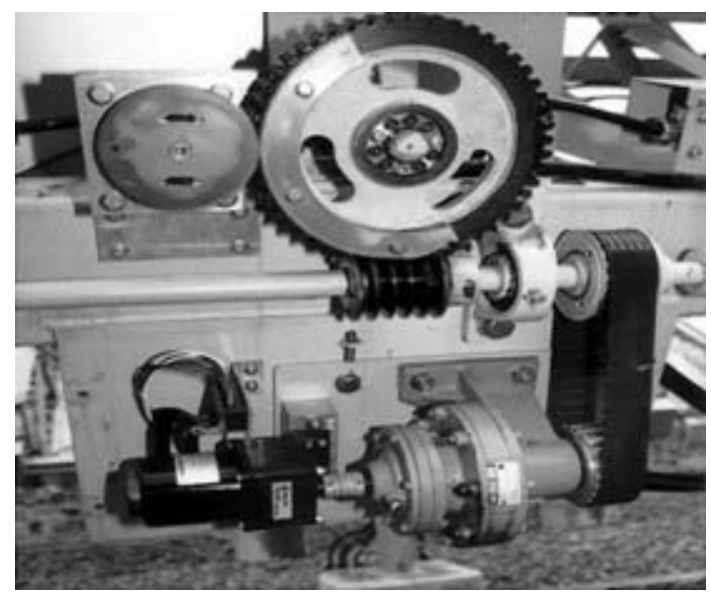

Fig.13. Close-up of 1-axis-sun tracker, with rotary en-code mounted on big gear (NEC Corporation, Kansai Electric Power Co., Inc.).
ているかのごとく大きい.しかも,直流電気とはいっても 太陽電池が生み出す電気であることから，いわゆる定電流 領域と定電圧領域を持った太陽電池特性をもっている.さ らに太陽電池の表面温度も日射変動で, 大きく変化する . したがって ,太陽電池の出力を効率よく引き出すには高速 かつ精密に動作する最大電力追従システム ( = Pmax 追従 機能) が不可欠となる.残念ながら最近は, 集光式太陽光 発電システム対応の最大電力追従システムに関する報告

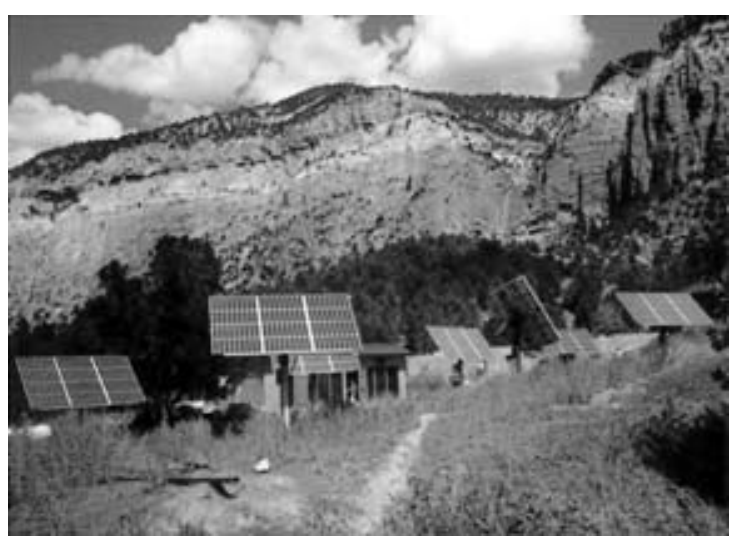

Fig.14. Flat-panel type PV generation system mounted by sun tracker (USA).

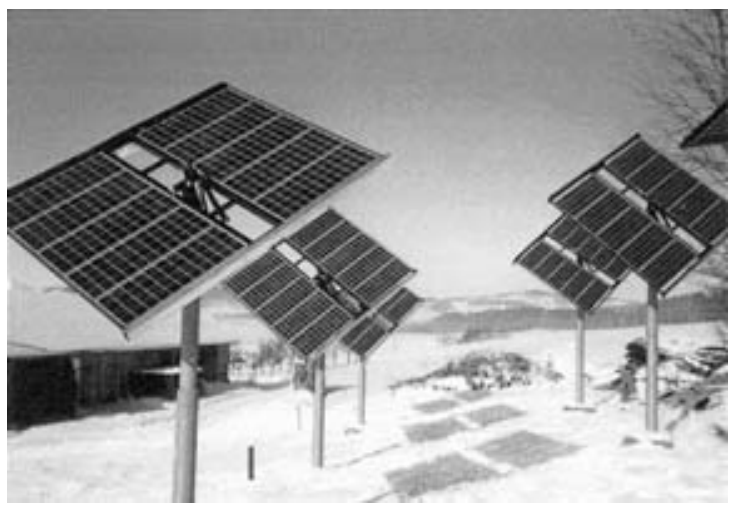

Fig.15. Flat-panel type PV generation system mounted by sun tracker (Germany).

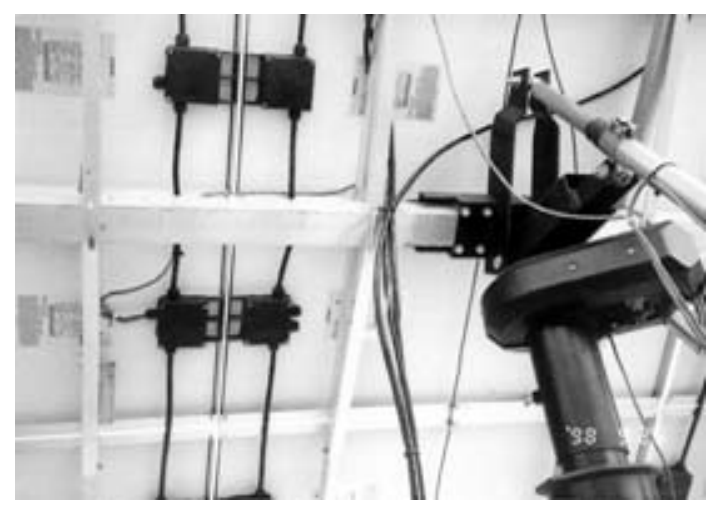

Fig.16. Solar tracking system mounted on rear side for flat panel type of PV generator (USA). 
はほとんど見かけない .もちろん，集光式太陽光発電用に 作られた直流交流電力変換装置自身の報告もほとんど見 かけない.このことは, 集光式太陽光発電システムの研究 開発は, 電力変換装置よりも, はるか手前の領域で行われ ており,電力変換装置に届くようなフルセット開発は最近 ではほとんど行われていないことを意味している .

\section{9. 集光式発電システムの開発に 固有の落とし穴}

集光式太陽光発電システムを構成する主要素としては 太陽電池, 集光装置, 追尾駆動装置, と電力変換装置があ る．弚れ光れは，あまり係わり合いのない分野ではある が，ここでは集合体を形成することが求められる．これは 意外と難しく落とし穴に陥りやすい，具体的には，

（1）集光式太陽光発電システムは, 太陽電池の価格低下に ついてゆけない .

太陽電池価格の低下は, 「平板式太陽光発電システム」 ではコスト低下に直接寄与する.太陽電池価格を集光倍率 の逆数にまで低くしている集光式発電システムは,システ ムコストに占める太陽電池の割合が極端に小さいので太 陽電池のコストダウンには直接結びつかない . したがつ て，相対的に「平板式太陽光発電システム」に対して，コ スト競争力を失うことになる.このことは，価格競争力の 弱い (システムコストの高い) 集光式太陽光発電システム は撤退を余儀なくされることになる .

（2）高性能部品を集めて組み合わせても，高性能なシステ ムとはならないことが多い

高变換効率の太陽電池と高性能 (高倍率, 低損失) 集光 レンズとを組合わせても，高効率発電パネルとなるとは限 らない，逆に关のレンズが太陽電池を破壊することすら起 こり得る.高精度な追尾駆動装置といえども，太陽光発電 パネルを組み合わせると「始動卜ルク不足」「消費電力過 大」,「構造・強度に余裕がなくなり，柔軟すぎて出力がふ らつく」,「点検停止後の運転再開で, 前方にいる太陽に遅 くて追いつけない」など, 発電パネルからの発生電気が低 品質になるのみならず, 出力が出ないなどの, 笑えない状 況も起こりかねない .

(3) 発電機とは呼べないようなシステム

太陽熱発電に使用されている発電システムはスチーム タービン発電システムである.太陽熱発電から太陽電池を 主体にした太陽光発電システムに移行する際，これまで発 電システムとは全く無縁であった分野からも参加が始ま ることになる．弚のころから，これまでとは全く異なる概 念か旣存の発電の世界に持ち込まれるようになった .关の
概念とは, 「光起電効果で発生する電子も，イオン効果で の電荷も, 摩擦電気も, 電気磁気効果で生まれる電気と同 じ電気である.電気にはなんら違いはない.これらは直流 電力とみなし交流に变換すれば電気事業が作る電力と同 じものとなる.発電機側で出力変更が勝手に行われても電 源であることに変わりはない .」というものである .

少なくとも発電と称するものが負荷とは無関係に出力 を変動させたり，遮断したりする概念は太陽熱発電システ ムの時代には存在しなかった . (現在でも, 新品の乾電池 や小型のエンジン発電機でこれが発生したらただではす まないことから，まだ旧概念は生きていると思われる．) 集光式太陽光発電システム開発途上でいろいろな問題が 発生したとき，光の解決方向を従来型発電機側に取るか， 光れとも新概念側に取るかで,光の過程も生ずる結果も全 く異なるものになる .

(4) 異なる分野の寄せ集め

太陽電池は半導体の専門, 集光レンズは光学専門, 追尾 駆動装置は機械構造専門, 追尾ソフトウエアは天文学専 門, 電力変換部はパワーエレクトロニクス専門と多種多樣 な専門分野が集まり開発が行われることになる．乥れぞれ の分野は「光れ光れ単独で高性能化をめざしたものを組み 合わせると, 総合的に良い性能が得られる.」いう基本的 考え方に乥って，独自に行動する．太陽電池は高変換効率 を目指す.集光レンズは高倍率低損失を目指す.追尾装置 は高精度低消費電力化を目指す .三者を組み合わせると極 めてバランスが悪いことになることがある.太陽電池表面 に集光による色収差や濃淡が出る，追尾精度が出ない，な どであり過乘性能に起因することが多い .この場合 2 次集 光系がこれを緩和するものとして提案されることがある . 2 次集光系はレンズと太陽電池の光路途中, しかもエネル ギー密度の最も高められたところに設置される光学部品 のため問題も多く,昔から論議の絶えない物である.問題 は集光レンズや太陽電池や追尾駆動装置を見直すか，关れ とも 2 次集光系を新たに採用するかである.乥れ光れの分 野が弚れ午れに高性能化を目指し始めたプロジェクトで は見直しより，2 次集光系の採用に進みがちである .

\section{0 . 集光式発電システムに潜む 落とし穴は他の新発電シス テムとも共通している}

太陽熱発電システムではいろいろ問題があるにしても， 少なくとも発電機としての資格を問われることはなかっ た .なぜなら発電機にはスチームタービンが回転してお り, タービンには蒸気が供給されており, 光の蒸気は, 蒸 
気溜槽で蓄えられているからである.すなわち発電機の背 後には完全な原動力を持った動力源が直結されているの である.電力系統における発電機，電動機，電力線等のシ ステムは，完全な動力て駆動される回転ホイールに対する 延長軸や延長ベルトシステムのようなものである. 発電機 はクラッチ, シャフトやベルトが電力線, 变圧器は変速ギ ア, 電動機が子ホイールである.したがって, 電力系統に おける発電機とは, 原動機が持つパワーを電磁気効果によ りリジッドに電力に変えリジッドに送り出す装置で,まさ にパワーをパワーとして変換しているものである .

しかしながら，太陽電池をはじめ, 燃料電池などの発電 素子を動力源と呼ぶには，無理がある。しかも直流を交流 に変化する電力変換装置も液体ではなく空気を媒体とす るトルクコンバータにたとえられ，これもまたパワー伝達 の観点からはみるとあまりにも軟弱である .

太陽光発電をはじめ,新発電システムを従来型発電機の 観点から評価し問題解決の方向性を見出すことは厳しい かもしれないが誤りや間違いの発生は避けられる．

\section{1 . 集光式太陽光発電システム の評価}

太陽熱発電システムの欠点を克服するものとして出現 した「集光式太陽光発電」は, 皮肉にも太陽熱発電よりも 短時間 (1980 年代前半) に光の最盛期を迎えた。光して， この「集光式太陽光発電」は太陽熱発電より後から出てき たにもかかわらず,太陽熱発電を追いつき,追い越せたか どうか, 疑問に感じている人は多い,さらに, 先行して衰 退の一途をたどっているとみなす人さえいることも否定 できない，逆に，集光式太陽光発電システムは，材料・部 材·性能・手法・構成について, 研究され, 改良され, 実 証され，実用化段階にまで到達したとみなす人もいる.集 光式太陽光発電システムは，異種技術の集合体であること から，一部分の性能に目覚しい進展があっても，付随する 別の部分とのマッチングがとれなければ, 総合性能の低下 すら引き起こしかねないものであるにもかかわらず,国内 外の技術関係学会で報告されるのは，これら限定された部 分についての, 華々しい性能・成果が多い, 華々しい性 能・成果発表の影で, 弚れに伴う問題点や欠点, あるい は，光の後の経過により，予想外の物であったことや，明 らかに失敗とみなされるような裏面について,明らかにさ れないことはこの分野でも起こりうる.したがって，この 種のシステムの評価や開発にあたって, 国内外の文献・資 料を多数収集・調査しても, 問題点や欠陥が見つかること はほとんどない. 問題や不具合報告が何一つ見つからない
からといって, 素晴らしいものだとの判断をしてはならな い.すなわち, 集光式発電システムを開発するに際して は,どのような発電機を作ろうとしているのか，をはっき り認識しておかなければならない .これか確定していない と,開発途中で起こる難題や，不具合への解決方向が見出 せず,時には解決とは逆方向へ加速していても気づかぬ事 になる.出来上がった集光式発電システムがどのような性 能を持った発電機なのかも把握しなければならない.出来 上がった集光式発電システムが目的を達成したかどうか の判断のみならず,価値をきめるためにも発電性能の評価 は不可欠である.集光式発電システムの性能確認が難しけ れば，どのような電気機器なら駆動することができるか， あるいは,安定稼動させることができるかだけでも知るこ とが大切である，発電機としての性能確認や実証評価に耐 えられないように見受けられた開発プロジェクトは早い 段階で姿を消している。

しかしながら，1990 年代以降になると, 集光式太陽光 発電システム開発では, 発電機性能の確認か取れていない 物，あるいは取れない物までが出現しはじめた(なにも集 光式に限ったことではないが).発電機性能の取れない集 光式発電システム」とは「新発電システムがとっている系 統連系化路線」に沿ったものである.「集光式太陽光発電 システム」が, 発電機性能を無視できるところのいわゆる 「系統連系化路線」をとると，これまでとは異なる難しい 局面に遭遇することになる.すなわち強力なライバルが立 ちはだかることになる.強力なライバルとは, 現在最も普 及拡大している「平板式太陽光発電システム」のことであ る.すなわち，「系統連系型」集光式太陽光発電システム は, この「平板式太陽光発電システム」に対して, 性能的 にも経済的にも，しかも 20 年以上の長期にわたり圧倒し なければならない．

\section{あとがき}

かつて「集光式太陽光発電システム」に本格的に取り組 み, 弚の後わずかながらでもかかわりを持ち続けた者が, 乥れについて，何かを記述することは極めて厳しい．なぜ なら, こ二数年間で, 毎年, 数万台から十数万台もの太陽 光発電システムが住宅の屋根などに設置されつづけ, 普及 拡大しているのは, 紛れもなく「平板式太陽光発電システ ム」であって「集光式太陽光発電システム」ではない . こ れに対し，「集光式太陽光発電システム」は世界中かき集 めてもこの十年間で3桁に届くかどうかのわずかなシステ 厶台数，まして，日本では 2 桁のシステム数に届くかどう かさえ疑問である．まさに風前の灯のような状況にある． 
圧倒的な「平板式太陽光発電システム」の現状を前にし て，これを無視し，「集光式太陽光発電システム」の殼の 中に閉じこもり，狭い分野でのみ通用する独自の技術論や コスト論を楽観的に展開することは容易でもあるし，見栄 えも悪くはない，しかしながら，弚れもまた，なんとも重 い気分になることは疑いない，「集光式太陽光発電システ ム」の「復活」，あるいは「将来」をうんぬんするには， 「太陽熱発電」がたどっていた発電機への世界，すなわち 「負荷に出力を合わせ , 要求されたときはいつでも能力の 限界まで電力供給をしつづける」という世界に戻ることが できるかどうかにかかっていると思われる なぜなら，(本 文ではあえて述べなかったが, ) 米国における「太陽熱発 電」は天然ガス燃焼装置 (いわゆる追い炊き装置)の付加 をもって, 問題解決を果たしたことからもうかがい知るこ とができる . 